\title{
BOND SALESMANSHIP
}

\author{
By William Foley,
}

Manager, Bond Department, Mercantile Trust Company, St. Louis, Mo.

The successful salesman of bonds must be born with a good personality and a quick mind, but his real success depends more upon his desire to know and thoroughly understand the bonds he sells, and upon his realization of the responsibility and dignity attached to his profession.

To sell bonds successfully, the salesman must be ever studious. It is quite as important for him to keep thoroughly posted on every happening in the financial world and on every change or tendency to change in the leading money markets, as it is for the doctor to keep in touch with the developments of the medical world or the lawyer with the latest decisions affecting his practice. The word "profession" has therefore been used with intent. Bond selling is a profession in that it necessitates studious and careful preparation, and, at all times, constant reading and study.

The prime requisite for a successful bond salesman is that he should be a glutton for knowledge, knowledge of the world of business, of affairs, of public opinion and of general conditions. He must read the newspapers with avidity, particularly the columns devoted to the editorials, to financial matters, and to the railroads. He must supplement this by careful reading of the financial papers and magazines, and by such text books and articles as appear from time to time.

To sell successfully, the salesman must know not only the issue he is offering, but nearly everything else that may arise in reference to financial matters. The clients of the salesman belong to the class that has shown the ability to gather money, and they have given, naturally, considerable time and thought to the subject of its investment. The largest factor in the personal equation in bond selling is the necessity that the client should realize that the salesman knows his subject. No one, of choice, goes to a bad lawyer for advice, nor to a physician who is behind the times, nor will 
clients buy bonds from a man who does not understand what he is selling.

The next important factor is the necessity for the realization of the responsibilities and dignity attached to the profession of bond selling, and of the duty to the client. The investing of money is a serious matter, and for the salesman who realizes it fully, there is a great field as a seller of bonds. Money in America accumulates very rapidly, the number of bond buyers increases each year, and the buyer of to-day will be in the market again next year and the year after. It therefore behooves the bond salesman to guard with sincerity the interest of the client, to the end that he may retain the business of his client, and establish for himself a reputation for honesty, conservatism and care. No immediate profit can make up for the loss of the client's business. The salesman who abuses the client's confidence to make sales above real values, or of indifferent securities, will gradually and surely disappear from the rolls. because he will soon have no clients. On the contrary the man who is faithful to his trust will add client by client, until the volume of his business becomes larger than ever hoped for.

For the same reason, it is necessary that the salesman should show fixity of purpose, and once he is satisfied that his house is safeguarding honestly and conscientiously his interests and the interests of his clients, he should remain with the firm until he can take his place as a partner.

The bond salesman who gains the trust of his clients, and builds up a business on the right lines, is creating a most valuable asset for himself, and one for which there is always a market value. Only a few days ago a salesman who has worked hard, has been conscientious at all times and has had success, said that it had been hard work, but the results were like a pension for life. Clients who come to have confidence in a salesman often rely entirely on his judgment. They not only rarely change to other salesmen, but recommend the salesman in the highest terms to their friends. A salesman who is losing his business must have some elemental weakness, and it is best for him and his house that his efforts should be turned early to other channels.

Some salesmen who are conscientious and have ability meet with only fair success. When this is so, it is probable that the sales- 
man is not a good judge of people or is failing to place his offerings properly before his clients.

In addition to the general requisites which have been spoken of before, there are certain points in salesmanship which should be developed. They are not tricks of salesmanship since they are honest and fair, but rather the factors which distinguish the good from the mediocre salesman. To take them up in order, it is perhaps well to speak of:

( I) Enthusiasm. While bond selling must of necessity be a business of cold facts and figures, there is a certain spirit of enthusiasm which aids in making sales. The salesman must feel that his offerings are absolutely good, so good that he recommends them with warmth and a hearty manner. He must at all times feel the merit, the intrinsic value and desirability of what he is offering.

(2) Centralization. When a new issue of bonds is brought to the salesman's notice he must study most carefully all of the information relative to the issue. He must mark, read and inwardly digest, he must analyze and compare. If the issue is really desirable, certain salient points will appear. While he must know everything in regard to the issue, let him in making his offerings draw especial attention to the points of desirability which have nost impressed him; the probability is that they will also impress his client. The same general remark will also hold true where the salesman has more than one issue to offer. He must not jump from one subject to another, and thus confuse the client and himself. Scattered shot is only good for small game.

(3) Observation. Under this head it is desired to recommend to bond salesmen the necessity for observation of the inclinations, ideas and opinions of the client. It is a good thing to emphasize those points in regard to a bond issue which appeal to the client. Likewise, under this head, may be considered the important item of closing business. Many salesmen succeed in interesting the client. but do not close many sales. There can be no more desirable accomplishment in a salesman, than the realization of the proper time for making the business firm.

There are many pitfalls in the path of the bond salesman, and one dangerous quicksand. The latter is misrepresentation and the salesman who falls into it never recovers; his total disappearance is a question of but a short time. The bond salesman who misrep- 
resents any particular in regard to an issue of bonds to accomplish sales, has placed himself beyond the pale; he has betrayed the responsibility of his profession, and the faith of his client, and he deserves his fate. It is a pleasure though to consider that the morale of bond selling, both on the part of houses and salesmen, is high; and cases of misrepresentation are noticed chiefly on account of their rarity.

The pitfalls of salesmanship are numerous, and cause many troubles to the salesman. Fortunately these are not beyond repair, and to many salesmen a mere mention is enough. Briefly the following may be mentioned:

(I) The mistake of recommending bonds from the speculative standpoint. The salesman should sell his bonds on the basis of their absolute goodness and price as compared with other securities of equal excellence. Safety, income and convertibility are the great merits of good bonds. The wise salesman will not try to prophesy the movement of the market or the trend of money.

(2) The mistake of talking too much. It is always well to remember that the salesman's business is the affair of his house and his client, and he has no moral or other right to talk about it. Many desirable clients are lost through the tendency on the salesman's part to talk of his business.

(3) Unfair-competition. No salesman has ever made an ultimate gain by belittling opposition houses or criticising their offerings. This policy often results in the loss of faith on the part of the client, a poor opinion of the salesman himself, and scepticism of the offerings of his house.

In this paper no effort is made to write of bond salesmanship in any other than the most general way, and what has been written will apply equally well to the office salesman or the one who goes out to make sales by solicitation. But there is another class of bond salesmen who contribute a large percentage of the total sales, that is the salesman who talks well on paper. Circulars and letters from the various investment houses go out to investors in surprising numbers, and it is safe to say that the class of literature sent out, the care in its preparation and the general form contribute largely to the impression formed in the investors' minds regarding the conservatism of the house and the character of the bonds offered. The salesman who prepares the circulars and dic- 
tates the letters is a most important factor in the success of the business.

To prepare and write good bond-selling literature is an accomplishment, and requires a thorough knowledge of conditions, statistics and facts, as well as ability to write good, strong English. Good salesmen of this kind are rare, and are often of more value to the house than the men who meet the clients. Their work is not showy, and often is not appreciated for its full value.

No effort has been made in this paper to write on the duties or preparation of the salesmen who are "in the street," whose work it is, wherever there is a well-defined market, to go about the banks, insurance companies and other bond houses with offerings; since in these cases the clients are themselves experts on bonds, the buying becomes simply a matter of trading. Rather, it has been the effort to write of bond salesmanship where there are difficulties to overcome, and where the relations of confidence and trust are established.

The responsibility of the bond salesman's position cannot be too strongly emphasized. It often comes to him to invest the savings of the old, the funds of trust estates, the legacies of widows and orphans and the surplus funds of business men. There can be no position more filled with responsibility. To be successful, the bond salesman must live up to his responsibility. 